\title{
NEW YORK-APPROVED MEXICAN DIVORCES: ARE THEY VALID IN OTHER STATES?
}

A New York husband travels to El Paso, Texas, crosses the international border and signs the municipal register of the town of Juarez in the state of Chihuahua, Mexico, a procedure sufficient to give the Mexican divorce court jurisdiction according to the laws of Chihuahua. He then files a petition for divorce with a district court in Juarez and returns to El Paso. The following day his wife, remaining in New York, files an appearance in the Juarez court through an attorney duly authorized to act for her. She submits to the jurisdiction of that court and admits the allegations of her husband's complaint. The court hands down a decree of divorce to the husband on the same day. ${ }^{1}$

When the second husband of the wife divorced under such circumstances brought annulment proceedings against her on the ground that the Mexican divorce was void and that she had therefore never been in a position to remarry, the New York Court of Appeals was confronted with the problem of what effect to give such a divorce. In Rosenstiel $v$. Rosenstiel $^{2}$ the court recognized the Mexican decree as valid, making New York the first American jurisdiction whose highest tribunal has sanctioned the bilateral ${ }^{3}$ Mexican divorce. ${ }^{4}$

1 See Samuels, To Juarez on the Divorce Run, N.Y. Times, Sept. 12, 1965, § 6 (Magazine), p. 78, where the details of the procedure for procuring bilateral Mexican divorces are discussed. Although critical of the "wholesale" Mexican divorce procedure, the article questions the wisdom of a New York divorce law which is so strict that many New Yorkers feel compelled to resort to the Mexican courts to dissolve their marriages. See also 14 Buffalo L. REv. 556 (1965); 33 FordHaM L. REv. 449 (1965).

216 N.Y.2d 64, 209 N.E.2d 709, 262 N.Y.S.2d 86 (1965).

3 A bilateral divorce is often called a "participating" divorce. Both parties participate in the suit and submit to the jurisdiction of the court. There need only be a personal appearance by one party, but the other must at least file an appearance through an attorney.

A bilateral divorce proceeding differs from an ex parte proceeding, in which only one spouse appears before the court, the other not having submitted to its jurisdiction. The ex parte proceeding usually arises where the spouses are in different states and the forum in which one brings suit does not have personal jurisdiction over the other. An ex parte divorce granted in one state must be accorded prima facie validity in every other state, Williams v. North Carolina, 317 U.S. 287 (1942), but it may be attacked and set aside on the ground that the procuring spouse did not establish bona fide domicile in the divorce rendering state. Williams v. North Carolina, 325 U.S. 226 (1945).

4 The New York Court of Appeals has, however, indicated that ex parte Mexican divorces of New York domiciliaries are void in New York, see Rosenbaum v. Rosenbaum, 309 N.Y. 371, 130 N.E.2d 902 (1955), and has held that Mexican "mail order" divorces are void. See Caldwell v. Caldwell, 298 N.Y. 146, 81 N.E.2d 60 (1948). A mail order decree may be procured without ever leaving the home state. Each spouse simply executes a power of attorney directing a Mexican lawyer to represent him or her in a divorce proceeding and mails it to Mexico. A divorce decree valid in Mexico is soon returned. Referring to the mail order divorce, the court in Caldwell said, "There is not even the slightest semblance or color of jurisdiction justifying action by a court." 298 N.Y. at 150, 81 N.E.2d at 62.

Even ex parte Mexican divorces, which are ostensibly void ab initio, have been held to create some rights, however. See Estate of Borax v. Commissioner, 349 
In addition to generating controversy as to the wisdom and propriety of this "back door" 5 liberalization of New York divorce law, Rosenstiel raises a significant collateral issue in the area of conflict of laws: What will be the impact of the decision on other states which have either expressly refused to recognize bilateral Mexican divorces of their own domiciliaries ${ }^{6}$ or have not yet spoken directly to the issue ${ }^{7}$ This problem could arise when a New Yorker who has procured a bilateral Mexican divorce later moves to State $X,{ }^{8}$ remarries and makes his matrimonial domicile there. If the validity of the divorce is challenged, State $X$ must decide whether to recognize the Mexican decree, applying the law of New York, or to refuse recognition in accordance with its own law. ${ }^{9}$

Often divorces which would be voidable because the parties lacked bona fide domicile in the divorce rendering state are protected from subsequent attack either within or without that state by the principle of res judicata. The Supreme Court in Sherrer v. Sherrer ${ }^{10}$ held the full faith and credit clause to require that a person be prohibited from attacking the

F.2d 666 (2d Cir. 1965), in which the court held that an ex parte Mexican divorce of a New York domiciliary was to be given effect for federal income tax purposes, although it had been declared invalid to dissolve the first marriage by a New York court in a declaratory proceeding brought by the nonparticipating spouse.

5 New York law retains adultery as its solitary ground for divorce, N.Y. DoM. REL. LAW $\$ 170$; see note 1 , supra.

A joint legislative committee of the New York State Legislature has recently completed proposals for divorce law revision. The bill would add to the existing single ground for divorce several new grounds-cruel and inhuman treatment, including mental cruelty if it endangered the health of the other spouse; abandonment by one spouse for at least two years; a sentence to prison of a spouse for at least five years, without parole, for commission of a major crime; and a mutually agreed upon separation for at least two years. In addition, the adultery ground would be broadened to include homosexuality or sodomy. See N.Y. Times, Dec. 28, 1965, p. 1, col. 6; id. p. 17 , col. 6 .

- Several states have held bilateral Mexican divorces of their domiciliaries void. See Warrender v. Warrender, 79 N.J. Super. 114, 190 A.2d 684 (App. Div. 1963), aff'd per curiam, 42 N.J. 287, 200 A.2d 123 (1964); Golden v. Golden, 41 N.M. 356, 68 P.2d 928 (1937) ; Bobala v. Bobala, 68 Ohio App. 63, 33 N.E.2d 845 (1940).

7 One state which does not have a direct holding on the question of recognition has implied that Mexican divorces may be valid. See Commonwealth ex rel. Thompson v. Yarnell, $313 \mathrm{~Pa} .244,169$ Atl. 370 (1933) (dictum); Commonwealth v. Doughty, $187 \mathrm{~Pa}$. Super. 499, 144 A.2d 521 (1958) (by implication). See also Taintor, 1958-59 Survey of Pennsylvania Law, 21 U. PITT. L. Rev. 154 (1959).

8 State $X$, for the purpose of this discussion, will be assumed to have decisional law rejecting as voidable bilateral Mexican divorces of its own citizens.

9 An attack on a foreign divorce decree may arise in any one of a number of procedural settings such as annulment proceedings, Cocco v. Cocco, 23 Conn. Supp. 275, 181 A.2d 266 (Super. Ct. 1962); criminal prosecutions for bigamy, Williams $\mathrm{v}$. North Carolina, 325 U.S. 226 (1945); Williams v. North Carolina, 317 U.S. 287 (1942) ; State v. DeMeo, 20 N.J. 1, 118 A.2d 1 (1955); petitions for shares in estates, Johnson v. Muelberger, 340 U.S. 581 (1951) (facts set out in text accompanying notes 11 and 12 infra); petitions of children to establish legitimacy, Urquhart $v$. Urquhart, 272 App. Div. 60, 69 N.Y.S.2d 57, aff'd mem., 297 N.Y. 689, 77 N.E.2d 7 (1947); claims for widows' benefits under social security, Sherman v. Federal Security Agency, 166 F.2d 451 (3d Cir. 1948). In Sherman the plaintiff claimed the right to a benefit as the widow of a deceased wage earner insured under social security. The court found that it was proper for the agency to determine the validity of the decedent's divorce from his first wife in order to determine whether the plaintiff was his widow.

10334 U.S. 343 (1948). 
validity of a decree after having participated in the proceeding. The respondent in that case had appeared in a Florida divorce proceeding brought by his wife without attacking her allegation of Florida domicile. When later, in Massachusetts, he attacked the bona fides of the Florida domicile, the Supreme Court held that, having had one opportunity to do so, he would not be given a second chance. The decision being res judicata as to the husband in Florida, the Court held that full faith and credit required its also being res judicata in Massachusetts.

In Johnson v. Muelberger ${ }^{11}$ the Supreme Court further limited the assailability of bilateral foreign state divorce decrees. There the right of a daughter to attack the validity of her deceased father's Florida divorce was in issue. ${ }^{12}$ The Court held that a divorce which cannot be attacked on jurisdictional grounds by parties or strangers to the original proceeding in the decree rendering state cannot be attacked by them elsewhere. Finding that Florida law would not have permitted a collateral attack by the daughter, the Court concluded that the daughter therefore could not attack the divorce in New York. The full faith and credit clause was again said to control.

The effect of these two Supreme Court decisions has been, in essence, to render divorces by consent of the parties nationally cognizable. ${ }^{13}$ Although the full faith and credit requirements of the Supreme Court decisions apply only to bilateral sister state divorces, the rationale of the decisions seems applicable to bilateral Mexican decrees as well. Where both parties have submitted to the jurisdiction of the court and had full opportunity to contest the issues, there appears no reason to permit a later attack on the decree by either of the parties in the home state.

Courts have also applied a variation of the equitable estoppel doctrine in cases involving attacks on foreign divorces. This is an equity principle dependent upon events which may have occurred after the divorce was granted and results in a personal disability of the party attacking the decree rather than a bar based on the res judicata effect of the final decree. ${ }^{14}$ Thus a party who has procured a divorce is usually held estopped later to question its validity, even if it was an ex parte decree. ${ }^{15}$

Similarly, subsequent spouses of parties to divorces of questionable validity have been precluded from attacking the validity of the divorces even

11340 U.S. 581 (1951).

12 The daughter, as her father's legatee, was attempting to have the Florida divorce declared invalid in order to defeat the claims to his estate by the woman her father had married after procuring the divorce.

13 See Taintor, supra note 7 , at 155.

14 See Clark, Estoppel Against Jurisdictional Attack on Decrees of Divorce, 70 Yale L.J. 45, 47 (1960).

15 See, e.g., Cohen v. Randall, 137 F.2d 441 (2d Cir. 1943) ; Curry v. Curry, 79 F.2d 172 (D.C. Cir. 1935); Oberstein v. Oberstein, 217 Ark. 80,228 S.W.2d 615 (1950); Rediker v. Rediker, 35 Cal. 2d 796, 221 P.2d 1 (1950). Where both parties have participated in a sister state divorce proceeding, their rights are, of course, governed by the rule set down in Sherrer v. Sherrer, 334 U.S. 343 (1948) (discussed in text accompanying note 10 supra). 
where the rule of Johnson v. Muelberger, barring attack by strangers, is not applicable. In a typical case, Cocco $v$. Cocco, ${ }^{16}$ the plaintiff wife brought annulment proceedings against the defendant husband grounded on the alleged invalidity of the Mexican divorce the defendant had procured from his first wife. The court held that the plaintiff had no legal standing to bring the collateral attack on the decree:

Since plaintiff married the defendant after the Mexican divorce decree, of which proceedings she had knowledge, even before it was rendered, plaintiff had no legally protected interest which could have been affected by the decree itself at the time it was rendered. . . . The decree itself, far from adversely affecting the plaintiff's marriage to the defendant, was a basis of the validity of the marriage, and without which the marriage would have been bigamous ab initio. . . Plaintiff may not have the benefit of a standing or legal power of her own creation, not otherwise existent, to attack collaterally a divorce decree to which she was a stranger. ${ }^{17}$

Such reasoning indicates recognition of certain underlying values. Remarriage tends to produce circumstances which, from the standpoint of the community, make it more important to preserve the integrity of the challenged second marriage than to expose flaws in the divorce which preceded it or to resurrect the original marriage. ${ }^{18}$ In those instances where a participating spouse has been permitted to attack the validity of a Mexican decree, there has generally been no substantial reliance on the decree by either party prior to the attack. Thus in Warrender v. War-

1623 Conn. Supp. 275, 181 A.2d 266 (Super. Ct. 1962) ; accord, Weise v. Hughes, 1 N.J. Super. 104, 62 A.2d 695 (App. Div. 1948). But cf. Gerard v. Distefano, 84 N.J. Super. 396, 202 A.2d 220 (Ch. 1964), in which the court found that the husband bringing an annulment proceeding did not know of his wife's prior marriage and divorce when he married her. This lack of knowledge was the most important factor in giving the husband standing to attack the validity of the previous divorce decree. 1962).

17 Cocco v. Cocco, 23 Conn. Supp. 275, 277-78, 181 A.2d 266, 267-68 (Super. Ct.

18 Such considerations are clearly set forth in Judkins v. Judkins, 22 N.J. Super. 516, 537, 92 A.2d 120, 131 (Ch. 1952) :

Defendant now attempts to impeach the Arkansas divorce decree after having lived with plaintiff for more than five years, after she had borne him a son, and only after she charged him with having illicit relations with another woman. . . [H] e is estopped from now attempting to attack the foreign decree. He may not bastardize his issue, convert plaintiff's marriage to him into an adulterous, if not bigamous, relationship, and cast the shadow of possible illegality upon any marriage that the first husband may have entered into in the meantime.

But cf. Loiacono v. Loiacono, $179 \mathrm{~Pa}$. Super. 387, 116 A.2d 881 (1955), in which the court said it could not consider the hardships suffered by the second family of a man who had procured an ex parte Nevada divorce which was later attacked by his first wife, and that the divorce decree would be held void in Pennsylvania. See also Weiss, $A$ Flight on the Fantasy of Estoppel in Foreign Divorce, 50 Colum. L. REv. 409, 423-24, 428-32 (1950). 
render, ${ }^{19}$ where the wife who had been party to a bilateral Mexican divorce later attacked it, the attack was permitted. The court indicated that it had weighed a number of factors in permitting the attack, primary among which were the wife's immediate repentance of the divorce and the fact that neither party had yet remarried in reliance upon the decree. ${ }^{20}$ Except for situations like that in Warrender, however, it seems likely that in many jurisdictions the bilateral Mexican divorce of either a New Yorker or a domiciliary will never be successfully challenged by either party or by subsequent spouses who had knowledge of the divorce, particularly if there has been substantial reliance on the decree in establishing new living patterns.

Nevertheless, in instances where there has been no substantial reliance, and in jurisdictions such as State $X$, where direct attacks on the validity of foreign divorce decrees are permitted, the Rosenstiel decision presents new problems to persons emigrating from New York.

There are two pertinent situations with which the courts of State $X$ may be confronted: one, where New Yorkers who have procured Mexican divorces have had the validity of those divorces adjudicated in New York; the other, where there has been no adjudication of validity, only reliance on the holding of the Court of Appeals in Rosenstiel. ${ }^{21}$

In the first situation problems of full faith and credit come into play. The divorce was procured in Mexico but its validity was adjudicated in New York. It would seem that the courts of State $X$ may not reexamine the Mexican divorce itself, but are required to give full faith and credit to the New York adjudication of validity. Faced with an analogous

1979 N.J. Super. 114, 190 A.2d 684 (App. Div. 1963), aff'd per curiam, 42 N.J. 287, 200 A.2d 123 (1964). Accord, Golden v. Golden, 41 N.M. 356, 68 P.2d 928 (1937) ; Bobala v. Bobala, 68 Ohio App. 63, 33 N.E.2d 845 (1940).

20 The Warrender court quoted with approval the recital of illustrative considerations pertinent to the question of estoppel outlined in Hollingshead v. Hollingshead, 91 N.J. Eq. 261, 110 At1. 19 (Ch. 1920):

Among the facts and circumstances which are or may be material factors in such a controversy are whether the divorce decree is void or voidable; whether it was obtained by the present complainant, or was participated in by him; whether it was obtained with or without collusion or fraud upon the court, or fraud or duress upon the adverse party; whether the other spouse has since died, or married again; whether there are children by such second marriage; whether the complainant has "accepted the benefits" of the divorce, such as alimony, or by marrying again; whether or not the other spouse participated in the divorce, or acquiesced; whether complainant has been guilty of laches or undue delay; what the nature of the new suit is, and the motive or object of complainant in bringing it; whether the complainant is an original party to the divorce action, or a child, or heir or representative, and the like.

79 N.J. Super. at $121-22,190$ A.2d at 688.

21 A third situation is the one in which New York parties procured bilateral Mexican divorces prior to the Rosenstiel decision. Although courts could theoretically make a distinction between people in this situation and those who acted after the Rosenstiel decision, it seems unlikely that they will, since there were lower court decisions in New York recognizing bilateral Mexican divorces as valid prior to Rosenstiel. E.g., Caswell v. Caswell, 111 N.Y.S.2d 875 (Sup. Ct. 1952) ; Mountain v. Mountain, 109 N.Y.S.2d 828 (Sup. Ct. 1951). 
problem, the Supreme Court in Sutton v. Leib ${ }^{22}$ held that a New York decree annulling a Nevada marriage was binding in Illinois. In Sutton the petitioner wife brought suit in Illinois to recover alimony allegedly due from her first husband, the defendant. The petitioner had divorced the defendant in Illinois, gaining an alimony decree requiring monthly payments to her until she should remarry. Subsequently she married one Henzel, who had just procured an ex parte divorce decree in Nevada. When the Nevada divorce decree was attacked in New York by the first Mrs. Henzel, the nonparticipating spouse, the divorce was voided and the marriage of petitioner and Henzel annulled, all parties subjecting themselves to the jurisdiction of the New York court.

The Court, in upholding the New York adjudication of annulment and making it binding on all other jurisdictions, said:

If the Nevada court had had jurisdiction by personal service in the state or appearance in the case of Henzel and the first Mrs. Henzel, its decree of divorce would have been unassailable in other states. So as to the New York decree annulling the marriage, New York had such jurisdiction of the parties and its decree is entitled to full faith throughout the Nation, in Nevada as well as in Illinois.23

This holding lends support to the proposition that State $X$ would be required to extend full faith and credit to the New York adjudication of the validity of a bilateral Mexican divorce. If, as in Rosenstiel, the New York court had jurisdiction over both parties to the Mexican divorce, the principle of res judicata should apply. The parties should be able to rest assured that one full scale litigation of validity is sufficient to establish their marital status. It would be burdensome to leave them open to attack in every jurisdiction where they might establish residence. In short, New York judicial affirmation of a Mexican divorce should be treated like a divorce in New York in the first instance.

Assuming that State $X$ is required to recognize Mexican divorces which have been adjudged valid in New York, the question remains as to how to treat Mexican divorced New Yorkers where there has been no adjudication of validity. Now that Rosenstiel is settled law, it is unlikely that many New Yorkers will litigate the validity of their Mexican divorces. Under these circumstances the New Yorker who moves to State $X$ will have no judgment to which State $X$ will be required to accord full faith and credit. The problem facing the courts of State $X$ then becomes essentially one of choice of law-whether to apply its own law, hostile to Mexican divorces, or the law of New York as set forth in Rosenstiel.

22342 U.S. 402 (1952); cf. Harrison v. Harrison, 214 F.2d 571 (4th Cir.), cert. denied, 348 U.S. 896 (1954); Champion v. Champion, 20 IIl. App. $2 \mathrm{~d}$ 271, 156 N.E.2d 16 (1959).

23342 U.S. at 408 . The case was remanded to the circuit court but the only question left open to that court was the effect of the annulment on the defendant's obligation to pay alimony under Illinois law. 
There are few reported cases dealing with recognition of foreign divorces in a jurisdiction in which neither party resided at the time of the divorce. But those few cases are unanimous in holding that the law of the jurisdiction in which the parties were domiciled at the time of the divorce should be applied in determining the validity of the divorce. ${ }^{24}$ In Ball $v$. Cross, ${ }^{25}$ a New York case, the plaintiff husband, a New York domiciliary, alleged that his marriage to defendant was void because at the time it was contracted the defendant was married to another man. The defendant had married and lived in Missouri with her first husband. Subsequently her first husband left her and went to Nevada where he procured an ex parte divorce decree. The court said that if the defendant had been domiciled in New York at the time of the divorce, the Nevada decree would not have been recognized because of the Nevada court's lack of jurisdiction, but that

if the state of which she [defendant] was then a citizen recognizes such a decree as that obtained in Nevada, and gives it full force and effect, then it is not for us to say that it is void as to her. It is for that state to determine what its policy requires. It is the final judge as to how far, as to its own citizens, the principles of comity shall be applied. If the defendant is freed of all obligations of the Missouri marriage in the state of her domicile, she is freed everywhere. ${ }^{26}$

The apparent basis of this decision is persuasive. People anticipating divorce are most familiar with the law of their domicile; it is that law, if any, upon which they act in reliance. If, after having secured a divorce in a manner sanctioned in their home state, they establish residence elsewhere, it is unjust to defeat the reasonable expectations upon which they originally acted. State $X$, then, having had no relationship with the party or the divorce proceeding at the time it took place, should refrain from applying its law.

The idea that a sister state should apply New York's divorce recognition law, rather than its own, when it is ruling on the validity of the Mexican divorce of a person who was a New Yorker at the time of the divorce, seems to be in keeping with current conflicts thinking. The late Professor Brainerd Currie set down the following formulation for determination of the rule of decision in choice of law problems :

24 In re Lujan's Petition, 144 F. Supp. 150 (D. Guam 1956) (validity of petitioner's Mexican divorce to be determined by application of law of the Philippines, her domicile at time of divorce); Dean v. Dean, 241 N.Y. 240, 149 N.E. 844 (1925) (law of Canada governed question of validity of Pennsylvania divorce); Ball v. Cross, 231 N.Y. 329, 132 N.E. 106 (1921) (Missouri law governed on question of validity of Nevada divorce); Ini re Adams' Will, 142 N.Y.S.2d 32 (Surr. Ct. 1955) (Minnesota law governed question of validity).

25231 N.Y. 329, 132 N.E. 106 (1921).

$26 I d$. at 332,132 N.E. at 107 . The procedural setting of this case suggests that the court could have decided it on the basis of the equitable estoppel doctrine. Instead the court gave the plaintiff husband standing to attack the divorce, making no mention of the estoppel doctrine. The court went on to ground its decision solely on choice of law rules. 
1. Neither the Full Faith and Credit Clause nor the Due Process Clause prevents a state from applying its own law in preference to that of another state when the forum state has a legitimate interest in applying the policy embodied in the law.

2. The foregoing principle is subject to this limitation: Ordinarily, the interest of the forum state must have existed at the time of the transaction or events on which the rights of the parties depend. To apply domestic law when the forum state had no interest in the application of its policy at that time raises problems similar to those raised by the retrospective application of laws. That is to say, the law in question ought not to be applied unless the unsettling of private expectations can be justified by the urgency of the public purpose to be accomplished. ${ }^{27}$

In this situation Professor Currie's theory suggests that State $X$ ought to apply New York law. The interest of the sister state did not exist at the time of the divorce-the transaction on which the rights of the parties depend. The rights of the divorced parties became settled in New York and would be drastically unsettled by the application of another state's law. Such application would be an unfair interference with reasonable expectations. ${ }^{28}$

27 Currie, Full Faith and Credit, Chiefly to Judgments: A Role for Congress, 1964 Supreme Courr Rev. 89, 92-93.

28 It is not here suggested that State $X$ is constitutionally compelled to apply the law of New York; only that this would be the wiser choice. In Clay v. Sun Ins. Office, Ltd., 377 U.S. 179 (1964), the Supreme Court held it not inconsistent with due process for Florida to apply its statute nullifying a clause of a personal property insurance policy taken out in Illinois, in which state such a clause was valid. The Court stressed the fact that the contract was ambulatory-a "floater" policy-and that suit might have been brought in any one of several states. When the loss of property creating a claim arose in Clay, the policyholder had resided in Florida for several years. Thus the Court found nothing offensive in Florida's application of its law.

On the other hand, in Home Ins. Co. v. Dick, 281 U.S. 397 (1930), the Supreme Court held violative of due process Texas' application of its own law striking down a clause of an insurance contract with which it had no contact. The Court said:

[N]othing in any way relating to the policy sued on, or to the contracts of reinsurance was ever done or required to be done in Texas. A11 acts relating to the making of the policy were done in Mexico. All in relation to the making of contracts of reinsurance were done there or in New York. And, likewise, all things in regard to performance were to be done outside of Texas. Neither the Texas laws nor the Texas courts were invoked for any purpose, except by Dick in the bringing of the suit. Its [Texas'] attempt to impose a greater obligation than that agreed upon and to seize property in payment of the imposed obligation violates the guaranty against deprivation of property without due process of law.

Id. at 408 .

The situation considered in this Comment, in which a Mexican divorced New Yorker has left New York, remarried and established domicile in State $X$, falls somewhere between these two cases. State $X$, as the present domicile of the former New Yorker, would conceivably have enough interest in the status of the parties so that application of its own law would not violate due process. However, it seems clear that New York's interest in the validity of the Mexican divorce outweighs the interests later acquired by State $X$. Under the formulation here suggested, the combination 
It is of course impossible to anticipate every situation in which a challenge to a Mexican decree might arise. But if the bilateral Mexican divorce decree, coupled with New York domicile of both parties, is viewed as finally determining the rights and obligations of the parties just as a divorce procured in New York would, this difficulty is met. Such a conceptualization seems best to effectuate the underlying purposes of the Rosenstiel decision. Although on its face it is no more than a decision to recognize a certain kind of foreign divorce, there can be little doubt that Rosenstiel was in large part a response to the strictures of New York divorce requirements. ${ }^{29}$ The Rosenstiel decision, in reality, provides an avenue of divorce additional to that provided by statute. The court gave bilateral Mexican divorces the same standing that divorces procured in New York courts would have.

To require that Mexican divorced New Yorkers, in order to protect their divorced status against possible future attack, obtain an adjudication of validity before venturing into another state, would be an elevation of form over substance. Such a "friendly" adjudication, even if obtainable, and even if entitled to full faith and credit, would be a mere formality in light of the decision in Rosenstiel. The judicial process should be invoked only to deal with bona fide controversies, not be a partner to empty gestures in order to give extraterritorial effect to Mexican divorces. But if sister states refuse recognition to Mexican divorces of former New Yorkers, such a mechanical invocation of the New York courts is likely to result.

The wisdom and propriety of the Rosenstiel decision should not be open to attack by courts in other states. Disapproval of the decision provides no basis for penalizing bona fide ex-New Yorkers who relied on it as New York law. Thus the only question with which the State $X$ court should concern itself is whether the parties to the Mexican divorce under challenge were bona fide domiciliaries of New York. Considering that New York was the only jurisdiction having a direct interest in the Mexican proceedings at the time of the divorce and that the parties relied on New York law, the divorce should be given effect as finally determining the parties' status in all jurisdictions.

of Mexican proceedings and New York domicile gives the Mexican decree a stabilizing effect on the parties' status. This unique characteristic of the divorce decree, coupled with the parties' assumed reliance on New York law, makes the application of State $X$ law more objectionable than the application of Florida law in Clay.

29 Professor Henry Foster, commenting on the Rosenstiel decision said: "It is to be regretted that, as a matter of public policy, New York is forced into a position of extending wide tolerance toward migratory divorce to compensate for intolerance in its domestic divorce law.". Samuels, To Juarez on the Divorce Run, N.Y. Times, Sept. 12, 1965, \&6 (Magazine), p. 78. 